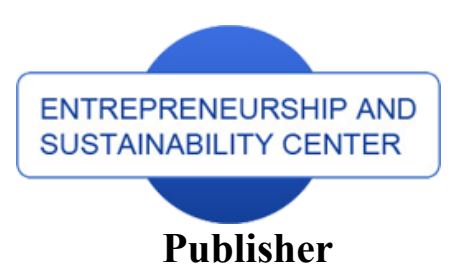

$\underline{\text { http://jssidoi.org/esc/home }}$

\title{
$\begin{array}{lll}1 & \text { Clarivate }\end{array}$

\section{URBAN INEQUALITIES IN ITALY: A COMPARISON BETWEEN ROME, MILAN AND NAPLES}

\author{
Keti Lelo ${ }^{1}$, Salvatore Monni' ${ }^{2}$ Federico Tomassi ${ }^{3}$ \\ ${ }^{1}$ Department of Business Studies, Roma Tre University, Via Ostiense 149, Rome 00154, Italy \\ ${ }^{2}$ Department of Economics, Roma Tre University; Via Ostiense 149, Rome 00154, Italy \\ ${ }^{3}$ Italian Agency for Territorial Cohesion, Rome, Via Sicilia 162, Rome 00187, Italy

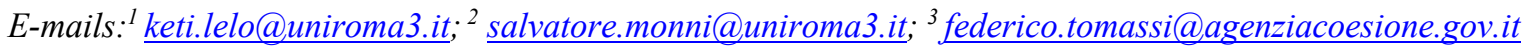

Received 15 September 2018; accepted 25 November 2018; published 30 December 2018

\begin{abstract}
The aim of this paper is to examine the spatial distribution of socioeconomic inequalities in the municipal territories of Italy's three most populous metropolitan cities, Roma, Milan and Napoli, by means of economic and social indicators and with data aggregated at the sub-municipal subdivisions of the cities and the municipalities in their provinces. These metropolitan areas are coming out of the worst crisis Italy has ever experienced, with a new class of poor people found not only in the outskirts and in the less well-off social groups but also among the middle class. Local and national governments cannot ignore this situation; the weakest sections of society have been unable to reap the benefits of the growth in the quaternary sector that has characterized Milan, Rome and Naples after the last decade, albeit to differing degrees.
\end{abstract}

Keywords: inequalities; spatial indicators; development economics; urban planning; peripheries

Reference to this paper should be made as follows: Lelo, K.; Monni, S.; Tomassi, F. 2018. Urban inequalities in Italy: a comparison between Rome, Milan and Naples, Entrepreneurship and Sustainability Issues 6(2): 939-957. http://doi.org/10.9770/jesi.2018.6.2(31)

JEL Classifications: O18, R28, R58.

\section{Introduction}

In the biggest Italian metropolitan cities, socio-economic inequalities and human development indicators show a marked territorial dimension, as they are geographically concentrated and sometimes sensitive to variations in distance from the city centre (Lelo et al., 2017, 2018). In order to better understand the particular nature of the phenomena, this paper compares Italy's three most populous metropolitan areas by analysing both the submunicipal subdivisions of the cities and the municipalities in their provinces: 155 districts and 120 municipalities for Rome, 88 districts and 133 municipalities for Milan, 30 districts and 91 municipalities for Naples. The 
comparative indicators used are taken from Istat 2011 Census*, and relate to the main variables that characterize the demographic, social and economic status of inhabitants: population density, foreigners, people aged under 30 and over 65 , graduates, and the employment rate $\uparrow$. In addition, the average taxpayer income as reported by the Revenue Agency in 2015.

The paper is organized as follows. Section 2 briefly introduces the recent causes of urban inequalities and provides some literature revivew. In section 3 we analyse urban inequalities, by describing and comparing some significant socio-economic indicators for Rome, Milan and Naples, both at sub-municipal level and for hinterland municipalities. Section 4 proposes some policy guidelines for such cities based on the data presented, together with some concluding remarks.

\section{Metropolization and inequalities}

The organizational and structural reformulation of space in the post-industrial age - with the transition towards a global post-industrial economy, based on IT and knowledge - has transformed the social and functional geographies of the big cities, leading to new forms of fragmented, heterogeneous and discontinuous territory (De Muro et al., 2011; 2012; Lelo, 2017; Kiselitsa et al., 2018, Mikhaylov, 2018). The so-called metropolisation process (Ascher, 1995; Sassen, 1996; Leroy, 2000), that since the end of the 70s has accompanied this transition, can be analyzed in terms of new divisions and spatial reconfigurations of labor, leading to renewed modes of production, distribution and consumption, and modified functions of the urban space (Gaschet et al., 2011). These functional mutations involve the urban form, creating complex urban structures that alternate areas of low density with "lumps" of residences, functions and productive activities (Glaeser, 2010). The spatial and functional fragmentation of the urban space undermines "classical" planning models, suggesting new interpretations of the underling transformation dynamics.

The main areas of investigation corresponding to intrinsic characteristics of each inhabited place - physical dimension, economic dimension and social dimension - have been addressed for long time making the sectoral reasons prevail to the interdisciplinary comparisons. The nature of these distinctions is to be found in the different ways of conceptualizing space and modeling the processes adopted by economists, urban planners, geographers and sociologists (Camagni, 1998). The relationships that link the process of metropolisation to the transformation of productive systems are treated by different strands of economic research. Although inspired by common principles inherited from the urban economy, the economic geography and the theory of endogenous growth, approaches remain heterogeneous and sometimes contradictory. Most of the studies do not explicitly refer to the concept of metropolization, but they are clearly linked to its economic background highlighting three main approaches: the contribution of economic geography and the inclusion of dynamic externalities in the process of urban growth (Glaeser, 1999; Duranton and Puga, 2005; Boshma and Iammarino, 2009); the economy of knowledge and its deployment to the concept of 'knowledge city' (Ovalle et al., 2004; Yigitcanlar et al., 2007); the concept of creativity and the creative city (Landry, 2000; Florida, 2002; Cohendet et al., 2010).

From the socio-spatial point of view, the new geographies of urban dispersion are increasingly considered as processes of opposite sign: decentralization and concentration, sprawl and density, homogeneity and inhomogeneity (Koolhas, 1997; Soja, 2000). The centrality of an area is no longer measured in terms of distance

\footnotetext{
* Although Census data depict the situation before the economic crisis, they make possible a homogeneous comparison over the whole national territory at municipal and sub-municipal level.

+ The Dataset is available in an open format at: http://mapparoma.blogspot.it/p/fonti.html. The data for Rome are net of nominal residences of immigrants and homeless people at associations and charities in some central districts.
} 
from the city center, but by the level of accessibility (Amin e Thrift, 2002) and the ability to integrate a plurality of uses and functions useful to the community (Pavia, 2002). These approaches, whose convergence with the economic sphere is limited, outline partial visions of the transformation processes involving today's metropolitan areas. It is not easy to effectively address socio-economic inequalities determined by the process of metropolisation. Traditional criteria used to analyse urban structures such as size, limits, spatial density, continuity, concentration and specialization of functions, must be able to integrate with variables able to grasp the underlying economic processes of production, distribution and consumption, and the socio-economic characteristics such as education and employment, amenities, integration and access to services for the socially weaker groups, identity and social ties.

\section{Rome, Milan and Naples: a comparison of three metropolitan cities}

In this paper we propose, with no claim to being comprehensive, some initial, comparative readings with regard to some indicators, held to be significant in terms of addressing socio-economic urban inequalities, of Italy's three most populous metropolitan areas: Rome, Milan and Naples. They are comparable in terms of resident population but not in terms of surface area, urban form and economic performance, and they also represent the traditional North-South divide in Italy (Table 1). These three areas differ in terms of territorial size: the provinces of Milan and Naples add up 274,000 hectares, half the size of the province of Rome which covers 536,000 hectares, a figure which is even more evident at municipal level, where the sum of Milan and Naples municipalities is only $23 \%$ of the territory of Rome. Rome is characterized by being a regional capital of exceptional size, whose administrative boundary includes large areas of countryside, while the urban areas of Milan and Naples go beyond even the administrative boundaries of the respective provinces, extending into the neighbouring ones.

Table 1. Italian metropolitan cities.

\begin{tabular}{|c|c|c|c|c|c|c|}
\hline Name & $\begin{array}{c}\text { Province } \\
\text { residents } 2017\end{array}$ & $\begin{array}{c}\text { Capital } \\
\text { residents } 2017\end{array}$ & $\begin{array}{c}\text { Area } \\
\mathrm{km}^{2}\end{array}$ & $\begin{array}{l}\text { Density } \\
\text { inh. } / \mathrm{km}^{2}\end{array}$ & $\begin{array}{c}\text { Municipalities } \\
\text { No. }\end{array}$ & $\begin{array}{c}\text { GDP } \\
\text { Billion } € 2015\end{array}$ \\
\hline Rome & $4,353,738$ & $2,873,494$ & 5,363 & 812 & 121 & 154 \\
\hline Milan & $3,218,201$ & $1,351,562$ & 1,576 & 2,042 & 134 & 161 \\
\hline Naples & $3,107,006$ & 970,185 & 1,179 & 2,635 & 92 & 55 \\
\hline Turin & $2,277,857$ & 886,837 & 6,827 & 334 & 316 & 70 \\
\hline Palermo & $1,268,217$ & 673,735 & 5,009 & 253 & 82 & 22 \\
\hline Bari & $1,260,142$ & 324,198 & 3,863 & 326 & 41 & 24 \\
\hline Catania & $1,113,303$ & 313,396 & 3,574 & 312 & 58 & 19 \\
\hline Florence & $1,014,423$ & 382,258 & 3,514 & 289 & 42 & 35 \\
\hline Bologna & $1,009,210$ & 388,367 & 3,702 & 273 & 55 & 38 \\
\hline Venice & 854,275 & 261,905 & 2,473 & 345 & 44 & 26 \\
\hline Genoa & 850,071 & 583,601 & 1,834 & 464 & 67 & 28 \\
\hline Messina & 636,653 & 236,962 & 3,266 & 195 & 108 & 11 \\
\hline Reggio Calabria & 553,861 & 182,551 & 3,210 & 173 & 97 & 8 \\
\hline Cagliari & 431,430 & 154,083 & 1,249 & 346 & 17 & 12 \\
\hline 14 cities & $21,948,387$ & $9,583,134$ & 46,639 & 471 & 1,274 & 663 \\
\hline$\%$ out of Italy & $36.2 \%$ & $15.8 \%$ & $15.4 \%$ & & $16.0 \%$ & $40.5 \%$ \\
\hline Italy & $60,589,445$ & $60,589,445$ & 302,073 & 201 & 7,960 & 1,637 \\
\hline
\end{tabular}

Source: Authors' analysis on ISTAT data. 


\subsection{Average income}

The average annual income per taxpayer is unequally distributed over the three metropolitan areas (Figure 1). Almost the entire territory of the province of Milan is in the over- $€ 20,000$ bracket, but Milan (average income $€ 30,600)$ is not the richest municipality: there are five richer hinterland municipalities with average incomes of over $€ 31,000$ (Basiglio, Cusago, Segrate, San Donato and Arese). In the province of Rome, the only two municipalities with an average income of just after $€ 25,000$ are Formello and Grottaferrata, located in the first hinterland ring, while Rome municipality remains just below this threshold at $€ 24,700$ (probably flattened by the effect of the internal variability over the extended municipal territory) and most of the other municipalities are in the $€ 15,000-€ 22,000$ bracket. Figures are very different in the province of Naples where, except for Capri, San Sebastiano al Vesuvio, Procida and Sorrento, the rest of the municipalities have an average income of less than $€ 20,000$; Naples has an average income of just under $€ 19,900$, and an elevated number of municipalities have an average of below $€ 15,000$. In the boxplots (Figure 2) the same data are displayed for all municipalities in the three provinces $^{\ddagger}$.

Figure 1. Maps of average income for taxpayer in 2015.
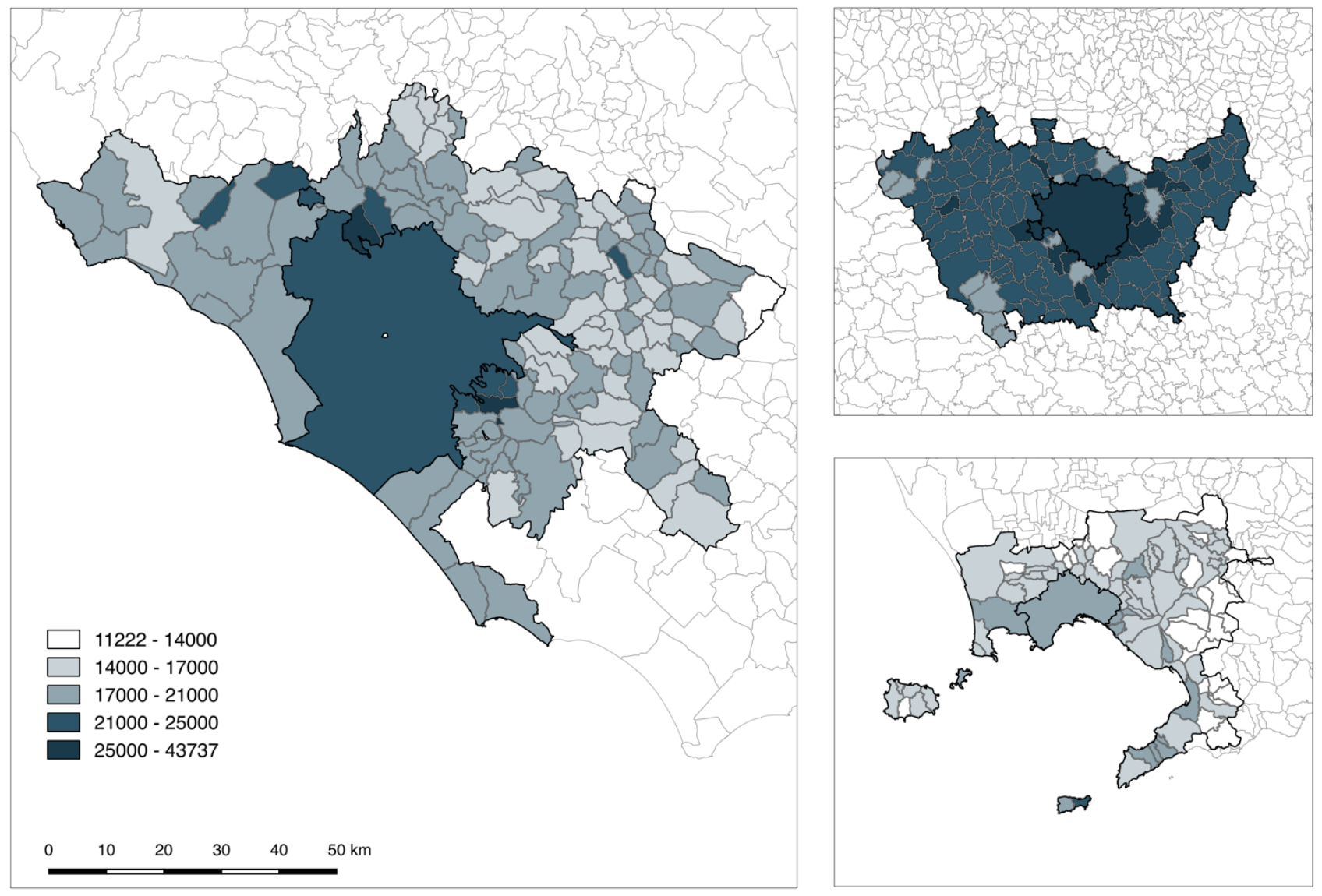

Source: Authors' analysis on data from the Ministry of Economy and Finance - Departement of Finance.

\footnotetext{
$¥$ Upper whisker $=$ maximum, upper box side $=$ third quartile, band inside the box $=$ second quartile (median), lower box side $=$ first quartile, lower whisker $=$ minimum .
} 
Figure 2. Boxplots of average income for taxpayer in 2015.

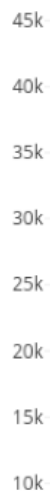

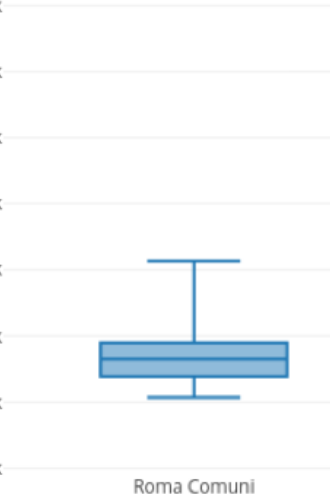

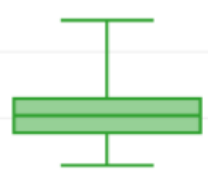

Napoli Comuni

Source: Authors' analysis on ISTAT data.

\subsection{Population density}

In all three of the provinces analysed, population density decreases as distance from the centre increases, reflecting the markedly monocentric structure of the main urban systems. However, the three cities examined here have particular characteristics that depend on the different administrative boundaries of the metropolitan territory (Figure 3).

Notably Rome, whose urban continuum is mostly included within the municipal boundaries, has a very high population density in the historical and intensive periphery belt inside the Orbital Motorway (Grande Raccordo Anulare, or GRA), and low density outside the GRA, except for the eastern sector and the coastline of Ostia, which have always been the most urbanized. The highest density of over 190 inhabitants per hectare is found to the east of the city centre (Gordiani, Don Bosco, Appio, Torpignattara and Tuscolano Nord), as well as in some areas to the west (Marconi and Eroi) and north (Saccopastore). The municipalities in the first hinterland ring, despite experiencing a marked demographic growth over the last few decades, in parallel with the growth in the building sector and in property prices, still have far fewer residents compared with Rome; they also remain separate from Rome's urban continuum. Figures greater than 10 inhabitants per hectare are only recorded in the area of the Castelli Romani to the south-east of Rome (especially Ciampino, Albano, Marino, Genzano and Grottaferrata), in some coastal municipalities (Ladispoli and Anzio) and to the north-east of Rome (Fonte Nuova and Guidonia).

Milan is different from Rome because its urban continuum goes beyond the boundaries of its municipality and even of those of its province, extending into the neighbouring province of Monza and Brianza. The density is therefore very high in all capitalist sub-municipal districts, apart from the non-residential ones, with over 170 inhabitants per hectare, similar to the levels in Rome, to the west of the city centre (Selinunte and Washington) and to the east (Loreto, Buenos Aires-Venezia, XXII Marzo and Umbria-Molise). The first hinterland belt is also very densely populated, more so than Rome, with over 50 inhabitants per hectare in the populous municipalities to the north between Milan and Monza (Bresso, Sesto San Giovanni, Cusano Milanino, Cinisello Balsamo and Cologno Monzese) and to the south-west (Corsico and Cesano Boscone), while it only registers low levels in the less urbanized and more agricultural sectors, on the borders with the provinces of Pavia and Lodi. 
The situation is the same for Naples, which is different from Rome due to its extremely dense urban fabric and is already joined to the north with the province of Caserta and to the south-east with the province of Salerno. The central districts of Naples, together with Vomerohill, are the ones with the highest density, over 200 inhabitants per hectare (San Lorenzo, Montecalvario, Avvocata, Pendino and Vicaria), which is higher than in Rome, while Mercato, San Ferdinando and Stella have more than 150 inhabitants per hectare. Some hinterland municipalities have the highest density in Italy, as well as the most populated towns that are not province capitals, given that Giugliano, Torre del Greco, Pozzuoli and Casoria have between 80,000 and 120,000 inhabitants. The density exceeds 100 inhabitants per hectare or is just below that, and is therefore much higher than in the hinterlands of Rome and Milan, in Casavatore and Melito (to the north), Portici and San Giorgio a Cremano (to the south-east), and around 70 per hectare in Frattaminore, Arzano, Cardito, Mugnano and Casoria (all to the north of Naples); it only falls drastically in the hillier areas, namely to the north-east towards Irpinia, to the south-east on the Sorrentine peninsula and on the island of Ischia.

Figure 3. Maps of population density per hectare in 2011.
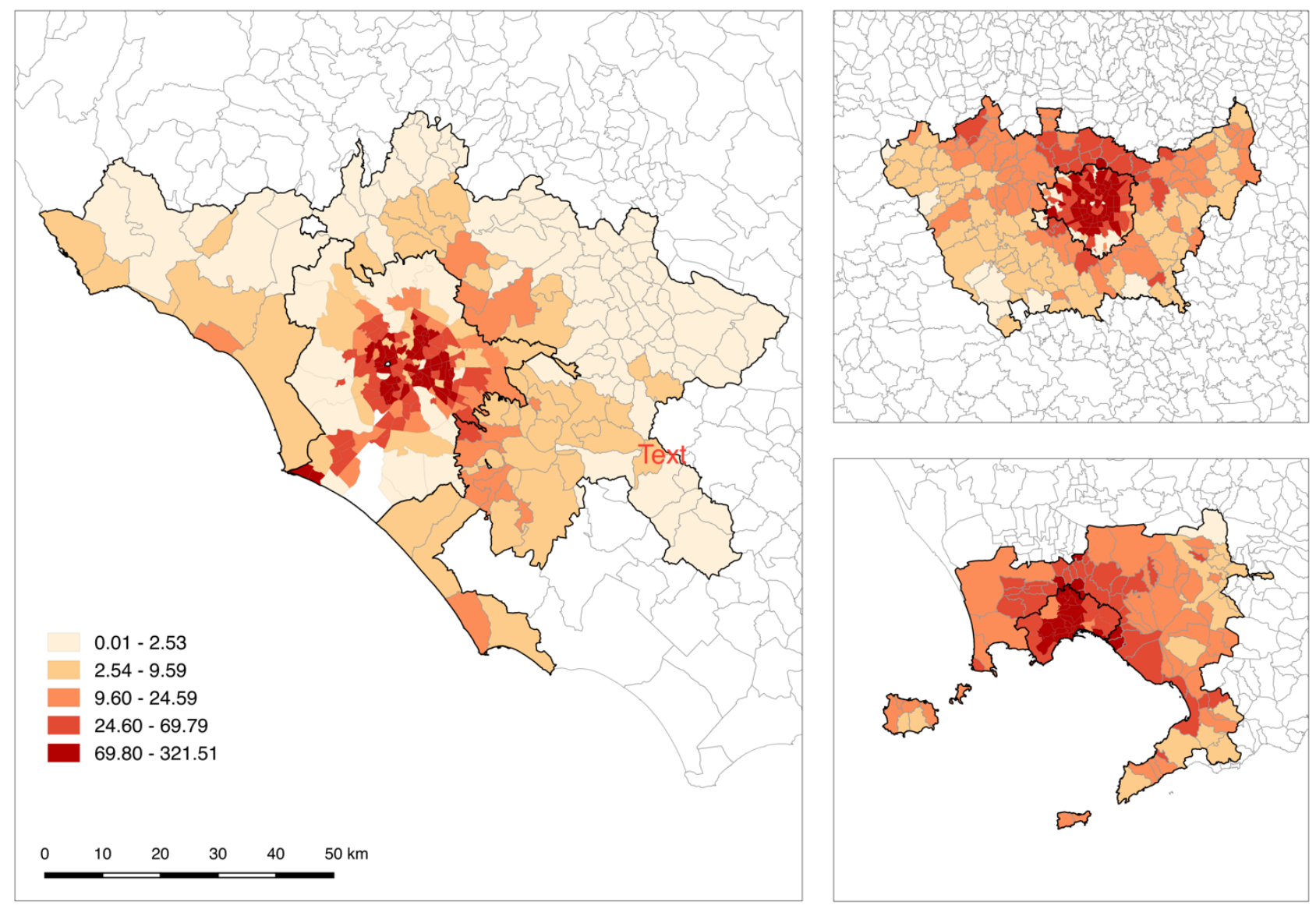

Source: Authors' analysis on ISTAT data. 


\subsection{Foreigners}

The share of foreigners appears to be very variable in the metropolitan cities of Rome and Milan, while it is uniformly low in Naples (Figure 4). With regard to foreigners, the territory of Rome does not present the rifts between the centre and the outskirts that usually characterize the demographic and socio-economic variables, given that they are not particularly concentrated in specific areas of the city. As a matter of fact the incidence of foreigners is over $15 \%$ (excluding the non-residential urban areas, and net of nominal residences of immigrants and homeless people) in very different districts, according to their country of origin and their jobs: in the well-off areas to the north and south where they perform domestic services there are many Filipinos and, to a lesser extent, Peruvians and Ukrainians (Grottarossa Ovest, Appia Antica Nord and Sud, and Parioli); in the east, there are many Chinese and Bengali people near businesses and restaurants which they either own or where they are employed (Esquilino, Quadraro, Casetta Mistica and Omo); in the districts near to or outside the GRA, accommodation costs less especially for Romanians, and to a lesser extent for Peruvians and Ukrainians (Tor San Giovanni and Tor Fiscale). In the hinterland the presence of foreigners displays similar trends, with a particularly high share of over $13 \%$ in municipalities with more affordable housing and which are closer to the city: the Tiber valley to the north (Civitella San Paolo, Ponzano, Campagnano, Rignano, Sacrofano and Riano), the north-east (Marcellina, Fonte Nuova, Sant'Angelo, San Polo dei Cavalieri and Poli), and on the northern coastline (Ladispoli).

In contrast to Rome, foreigners in Milan appear to be particularly concentrated in some suburban districts and in the first hinterland ring to the north and east of the city. The former include districts outside of the city centre, especially in the eastern sector, with figures of over $20 \%$, comparable to the figures for Rome, to the north-west (Affori, Comasina, Dergano, Farini, Bovisa, Villapizzone and Selinunte), north-east (Loreto and Padova) and east (Parco Monlué - Ponte Lambro, Ortomercato and Scalo Romana). In the most populous hinterland municipalities the incidence of foreigners is over $12 \%$ to the north between Milan and Monza (Baranzate, Cologno Monzese, Cinisello Balsamo and Sesto San Giovanni) and to the east (Pioltello and San Giuliano), as well as on the furthest point to the east on the border with the province of Bergamo (Vaprio d'Adda and Cassano d'Adda).

In Naples, however, there are limited numbers of foreigners both in the city itself and in almost all of its province, which is in sharp contrast to Rome and Milan. In the city, the share of foreigners is almost $12 \%$ in Zona Industriale only, while it is between 8 and $10 \%$ in a few central districts (Stella, San Lorenzo, Mercato, Pendino and Montecalvario), and falls below 1\% in the populous northern outskirts (Secondigliano, San Pietro a Patierno and Miano) and to the west (Soccavo). In the hinterland this share is just over $5 \%$, still far below that of the municipalities of the province of Rome, only on the islands (Forio d'Ischia, Capri, Serrara Fontana, Anacapri and Casamicciola Terme) and in a few Vesuvian municipalities to the east of Naples (Terzigno, Palma, San Giuseppe Vesuviano, Poggiomarino and Striano).

In the boxplots (Figure 5), as the next sections, the same data are displayed for all municipalities in the three provinces and for all districts of their capitals. 
Figure 4. Maps of share of foreign residents in 2011.
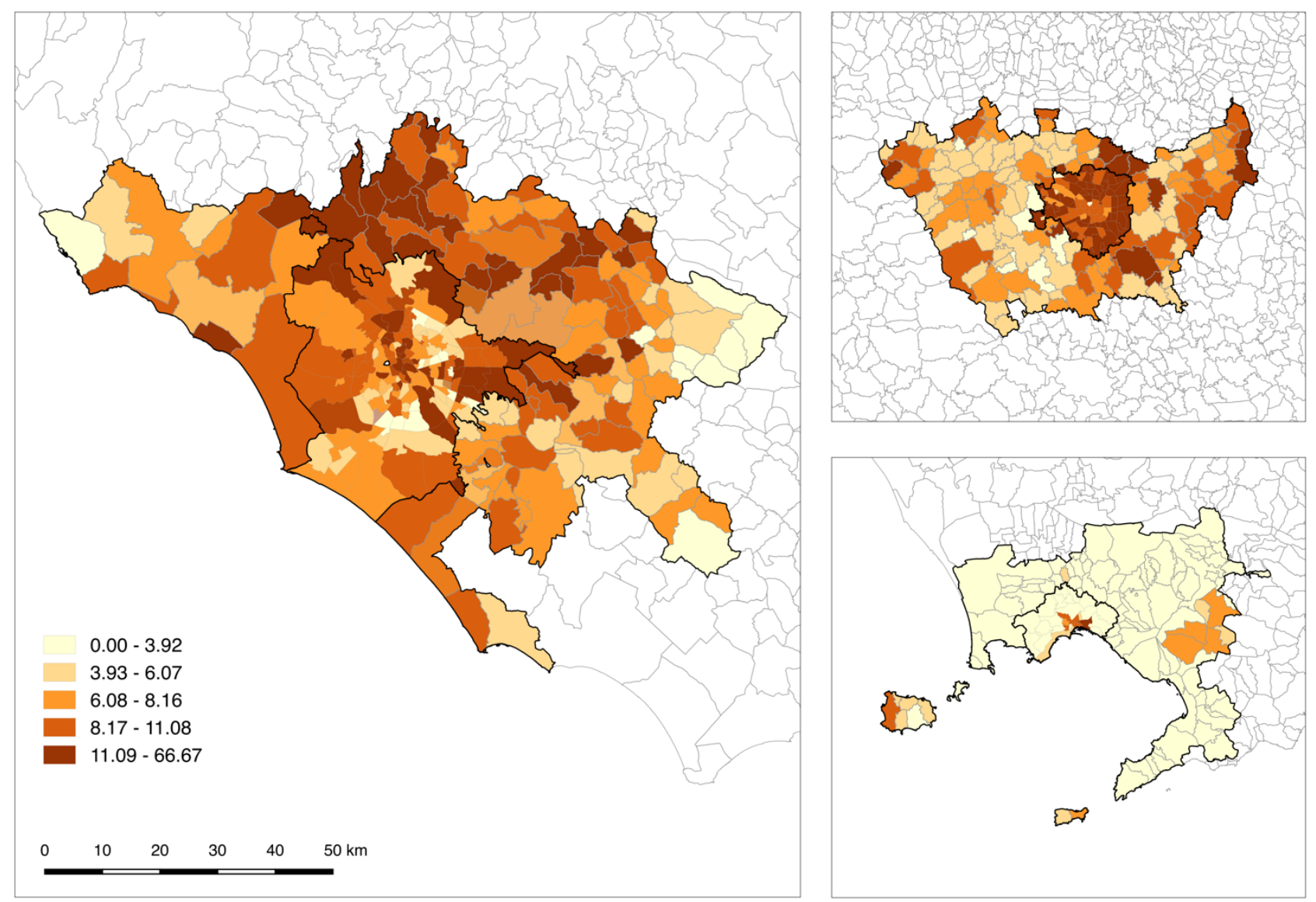

Source: Authors' analysis on ISTAT data.

Figure 5. Boxplots of share of foreign residents in 2011.

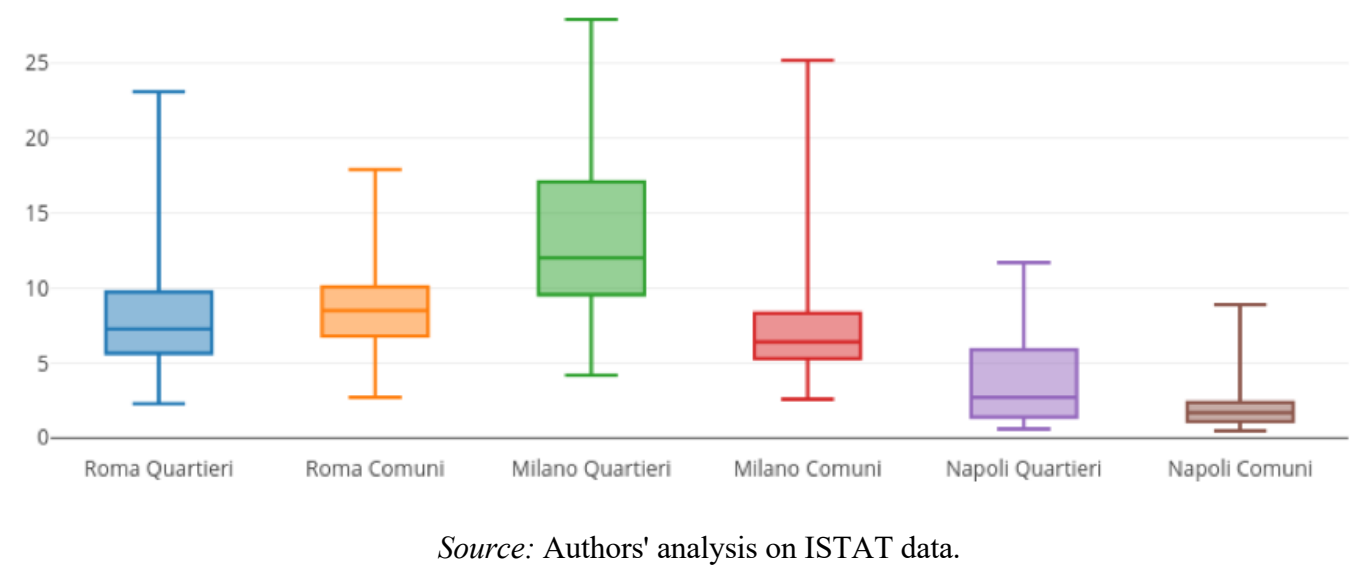




\subsection{The young and the elderly}

In the big cities the most central housing is becoming increasingly expensive, and is also shifting from the real estate market to the growing demand from tourism, thus giving rise to gentrification and 'airbnbization' processes and the displacement of residents, especially families, the remaining ones being mainly single people and widows/widowers, in any case with a high average age (Figures 6-9).

Roma is no exception, with young people under the age of 30 concentrated in the districts outside the GRA and in the hinterland municipalities undergoing a construction boom, while elderly people over the age of 65 mainly live in the central districts of the capital and in the municipalities furthest from the metropolitan city, where the population is lower. Young people account for over a third of the residents in the new districts on the outskirts of Rome to the east (Sant'Alessandro, San Vittorino, Borghesiana, Lunghezza and Barcaccia) and south (Vallerano Castel di Leva, Porta Medaglia and Santa Palomba), as well as in Santa Maria della Pietà inside the GRA to the north-west, while the elderly account for over $28 \%$ of the residents in the older outskirts to the west (Pineto, Aurelio Nord and Sud, Eroi, Colli Portuensi), east (Don Bosco, Torrespaccata and Pietralata), north (Conca d'Oro and Val Melaina) and south (Valco San Paolo and Navigatori). In the hinterland municipalities, young people account for over a third of residents only in the south-eastern area (Lariano, San Cesareo, Labico, Artena, Zagarolo, Valmontone, Lanuvio and Gallicano), as well as in Fonte Nuova and Mentana to the north-east, while the share of elderly people is biggest in the small municipalities in the mountains, the most populated of which is Carpineto (25\%).

In Milan, as in Rome, there are very few young people across almost all of the municipal territory, and only exceed $28 \%$ in a few peripheral districts to the south-east (Parco Monlué - Ponte Lambro, Triulzo Superiore and Rogoredo), north (Adriano, Comasina, Bicocca, Dergano and Quarto Oggiaro) and west (Muggiano and San Siro), as well as Pagano to the north-west of the city centre, while the elderly account for over $30 \%$ in the populous districts to the east (Parco Lambro - Cimiano and Mecenate), west (Gallaratese, Bande Nere and Lorenteggio) and south (Gratosoglio-Ticinello and Barona). In the hinterland municipalities, the share of young people is over $25 \%$ everywhere, though this figure is below that for Rome, with the highest figures (among the biggest municipalities) to the south (Basiglio, Pieve Emanuele and Zibido San Giacomo), east (Pioltello) and north (Solaro), while the percentage of elderly people is over $23 \%$ in the populous municipalities of the northern belt (Bresso, Cusano Milanino, Sesto San Giovanni and Novate), to the west (Corsico) and south-east (Melegnano), as well as in Magenta on the border with the province of Novara.

Naples also has a greater concentration of younger age brackets in the outermost areas of the province, and in contrast to the figures of elderly people in the city centre, but there are far more young people compared with Rome and Milan. The share of young people in the districts of Naples is consistently over than 27\%, and even reach figures close to or above $40 \%$ in the populous outskirts to the north (San Pietro a Patierno, Scampia, Piscinola and Miano), east (Ponticelli, Barra and San Giovanni a Teduccio) and west (Pianura), while the percentage of elderly people is only over $20 \%$ in the districts to the west (Arenella, Vomero, Chiaia, Fuorigrotta and Posillipo), as well as in San Giuseppe in the city centre. In the hinterland too, young people are almost never less than a third of residents, levels which are therefore higher than in Rome, and actually account for over $42 \%$ to the north of Naples (Melito, Casandrino, Crispano, Volla, Afragola, Qualiano, Sant'Antimo and Caivano) and to the south-east (Pimonte, Casola, Santa Maria la Carità and Lettere), while the elderly only reach $20 \%$ on the islands (Capri and Procida), on the Sorrentine peninsula (especially Sorrento) and in the municipalities of Portici and San Giorgio a Cremano to the east of Naples. 
Figure 6. Maps of share of residents under 30 in 2011.
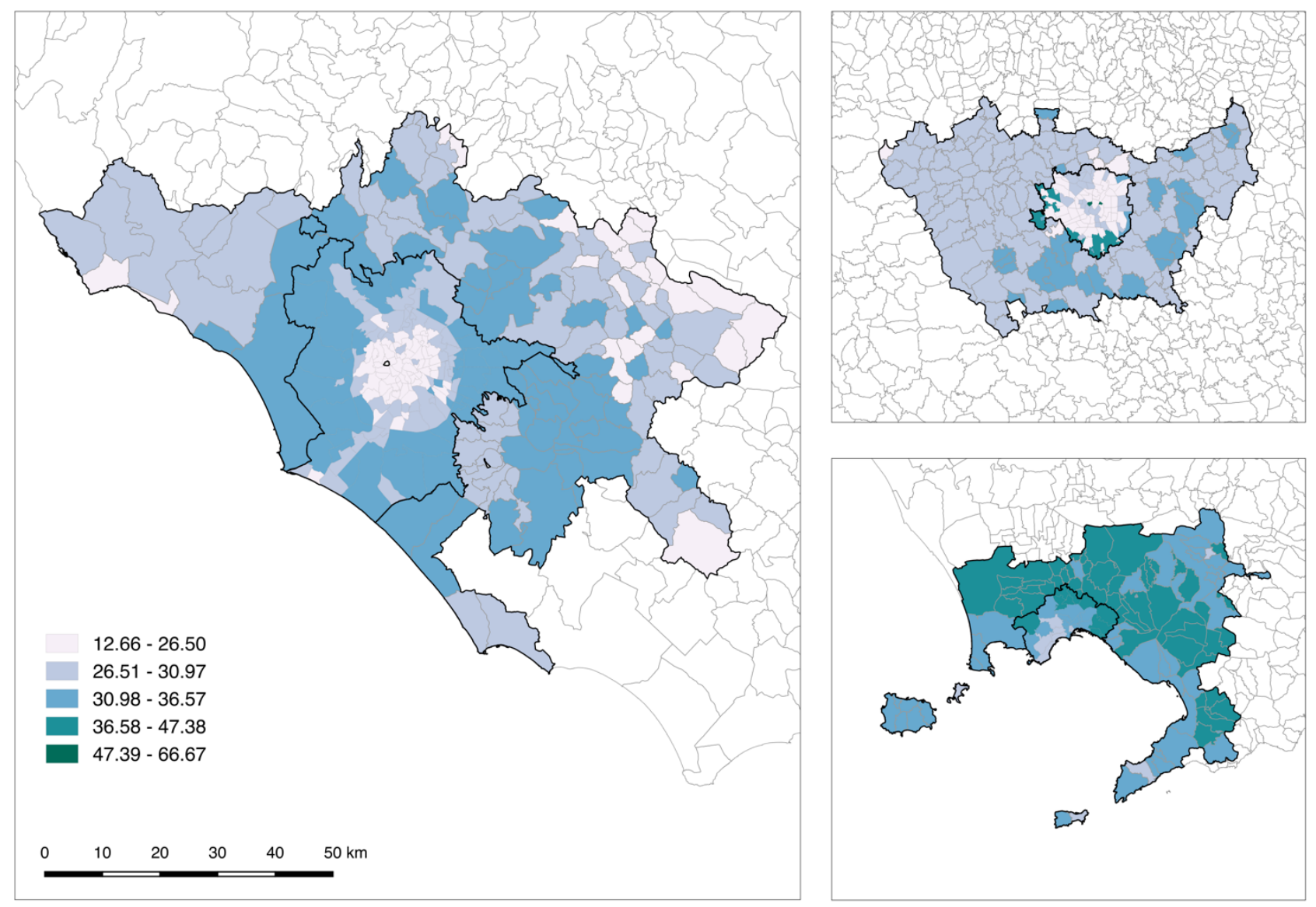

Source: Authors' analysis on ISTAT data.

Figure 7. Boxplots of share of residents under 30 in 2011.

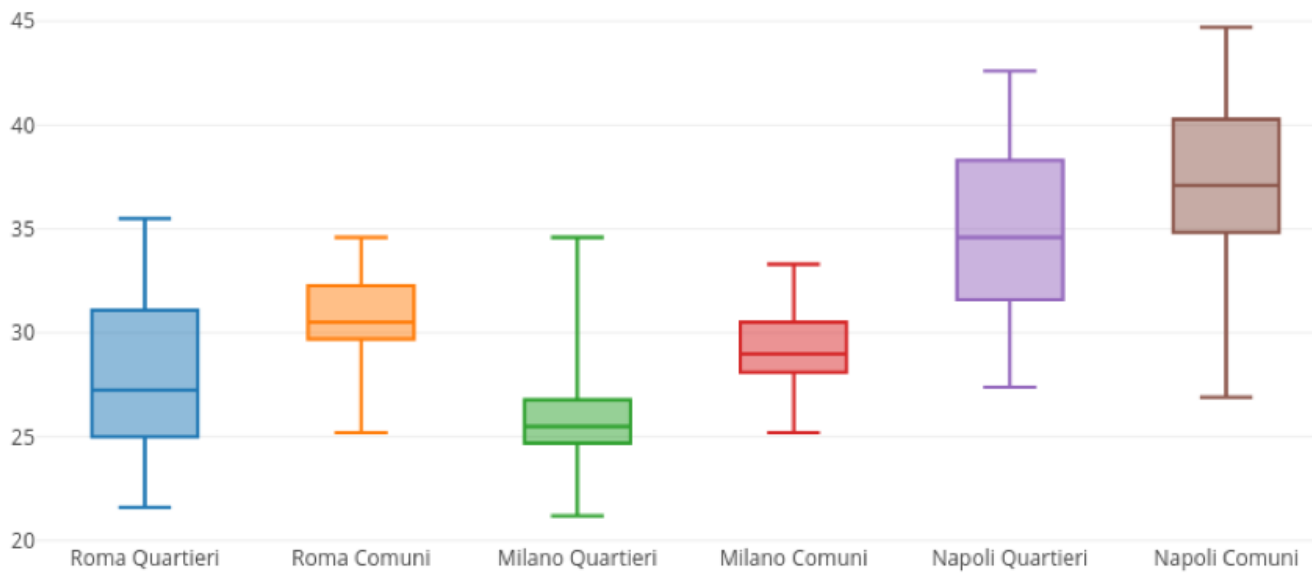

Source: Authors' analysis on ISTAT data. 
Figure 8. Maps of share of residents over 65 in 2011.
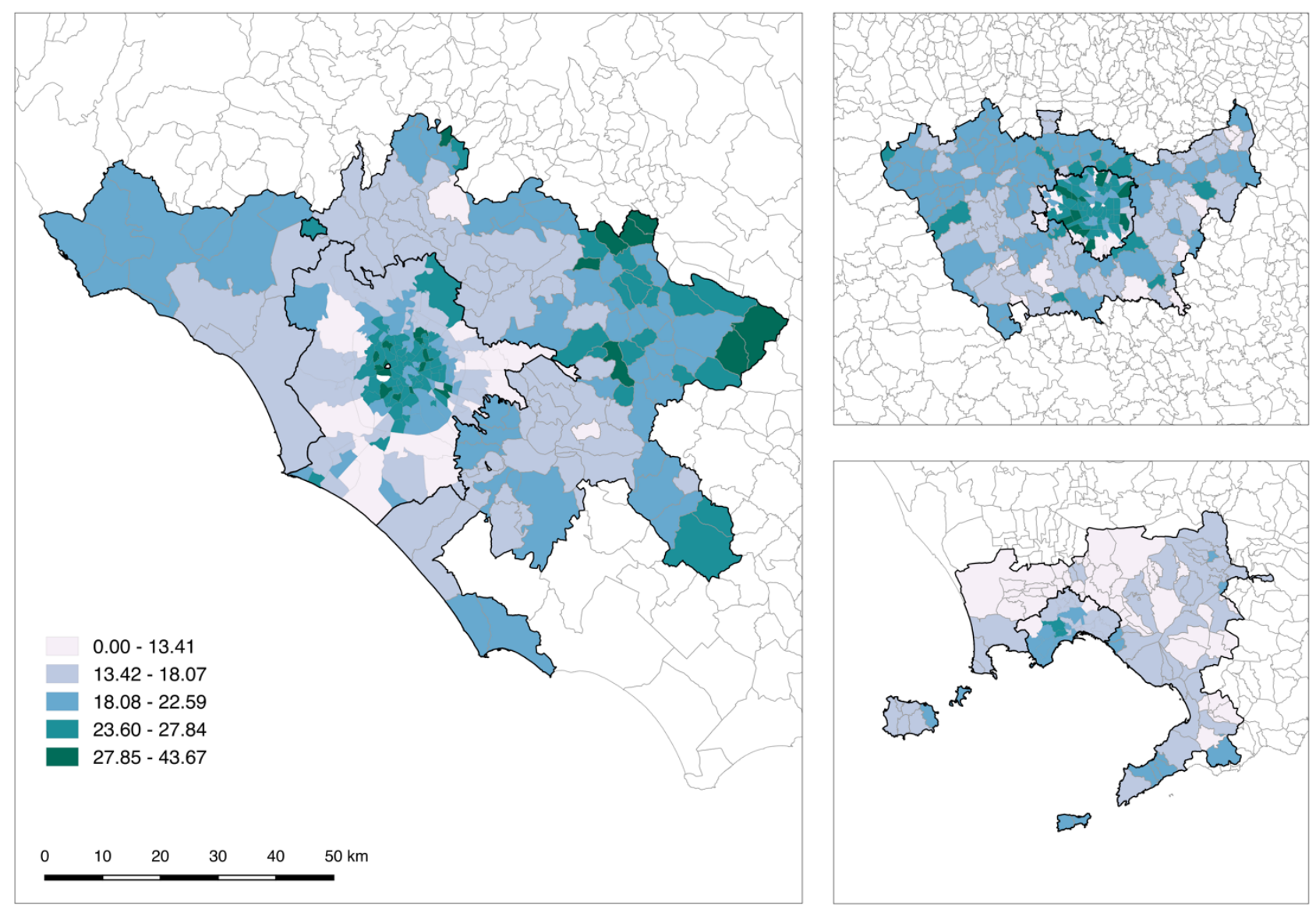

Source: Authors' analysis on ISTAT data.

Figure 9. Boxplots of share of residents over 65 in 2011.

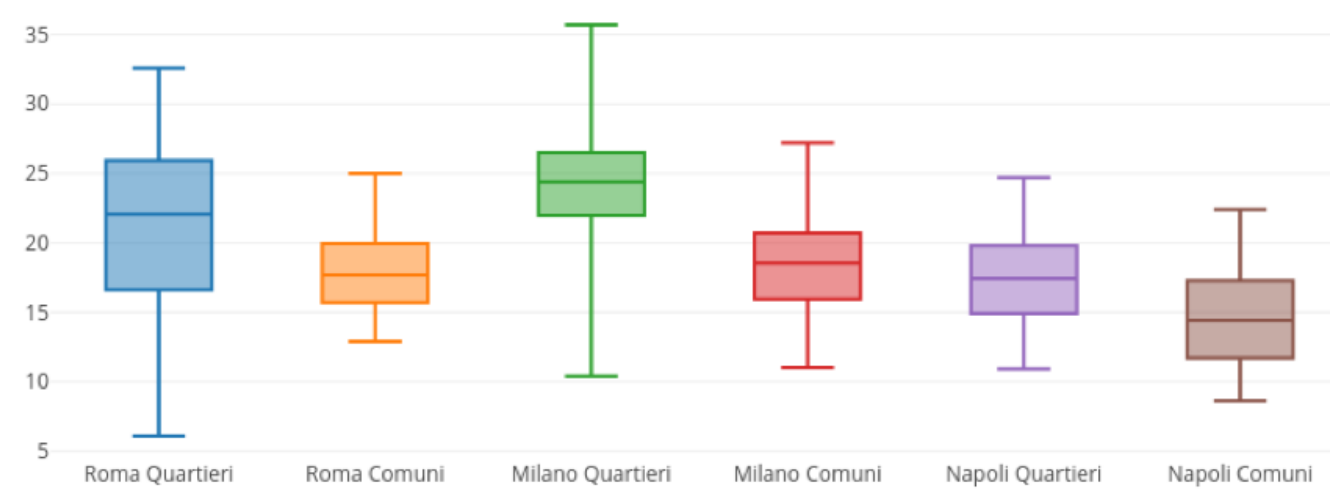

Source: Authors' analysis on ISTAT data. 


\subsection{Graduates}

Demographic characteristics influence the socio-economic composition of the various urban areas, especially the incidence of academic qualifications. In Rome and Milan there is a greater share of graduates in the most central districts and only in a few other hinterland municipalities, so that the distance from the centre is also a social distance, while in Naples the socio-economic problems in the city centre mean that the highest numbers of academic qualifications are concentrated above all in the well-off semi-central areas (Figures 10 and 11).

Specifically, in Rome municipality, there are eight times more graduates in Parioli (49\%) than in Tor Cervara (6\%). The share is over $42 \%$ in the well-off districts to the north (Parioli, Salario, Acquatraversa, Farnesina, Trieste, Medaglie d'Oro, Nomentano and Tor di Quinto), south (Eur and Navigatori) and in the centre (Celio, Centro Storico and Prati), while it is below 10\% especially in the outskirts close to or outside the GRA to the east (Tor Cervara, Borghesiana, San Vittorino, Torre Angela, Torre Maura and Giardinetti - Tor Vergata), as well as in Santa Palomba to the south and in Santa Maria di Galeria to the north-west. In the hinterland the share of graduates never exceeds 25\%, with the highest figures in the Castelli Romani area to the south-east (Grottaferrata, Monte Porzio Catone, Frascati and Nemi), in the Tiber valley to the north (Sacrofano and Formello) and around Bracciano Lake to the north-west (Trevignano, Bracciano and Manziana), while it is below 10\% in many municipalities to the south-east (Artena, Cave, Lariano, Valmontone, San Cesareo, Zagarolo, Ardea and Lanuvio) and north-east (Palombara Sabina and Fonte Nuova), besides those in the Apennines with many elderly people.

This divide is very sharp in Milan too, as in Rome, given that there are seven times as many graduates in Pagano and Magenta-San Vittore (both standing at 51.2\%) than in Quarto Oggiaro (7.6\%). The share of graduates is over $42 \%$ in the entire centre within the city walls and in the neighbouring districts (Pagano, Magenta-San Vittore, Duomo, Guastalla, Vigentina, Brera, Washington, De Angeli-Monte Rosa, Buenos Aires - Venezia and Ticinese), while it is below 12\% in the outskirts to the north-west (Quarto Oggiaro, Comasina and Bovisasca), west (Quinto Romano, Baggio and Figino), south (Barona and Gratosoglio-Ticinello) and east (Parco Monlué - Ponte Lambro). The figures are lower for the hinterland as they are in Rome, since - with the exception of Basiglio to the south $(34 \%)$ - the share of graduates never exceeds $27 \%$, with the highest figures found in the municipalities to the east (San Donato Milanese, Segrate, Cernusco sul Naviglio, Cassina de' Pecchi and Peschiera Borromeo), as well as in Arese to the north-west, while in many other municipalities the figure remains below 10\%, including (and only considering the most populous ones) Senago and Cinisello Balsamo to the north and Rozzano to the south.

The differences are even more marked in Naples compared with Rome and Milan, given that there are nine times as many graduates in Posillipo, Chiaia and Vomero (about $40 \%$, in any case fewer than in the other two cities) than in Scampia, San Giovanni a Teduccio and Miano (4.5\%). The share only exceeds 30\% in the well-off districts to the west (Arenella, together with those already mentioned) and in San Giuseppe in the city centre, but it falls below 10\% in the populous outskirts to the north (Scampia, Miano, San Pietro a Patierno, Secondigliano, Piscinola and Poggioreale), east (San Giovanni a Teduccio, Barra and Ponticelli) and west (Pianura and Soccavo), as well as in Mercato e Zona Industriale to the east of the city centre. There are also very few graduates in the hinterland, the highest figure being 15-17\% in Nola, in some municipalities to the east (Portici and San Sebastiano al Vesuvio) and on the Sorrentine peninsula (Sorrento, Sant'Agnello, Piano di Sorrento and Meta), and in any case fewer than in the provinces of Rome and Milan, while far too many municipalities have fewer than 7\%, including (only considering the most populous ones) many to the north (Crispano, Qualiano, Caivano, Arzano, Frattaminore, Casandrino, Afragola, Casavatore, Sant'Antimo and Casalnuovo) and to the south-east (Santa Maria la Carità and Sant'Antonio Abate). 
Figure 10. Maps of share of graduates on the population with 20 years or more in 2011.
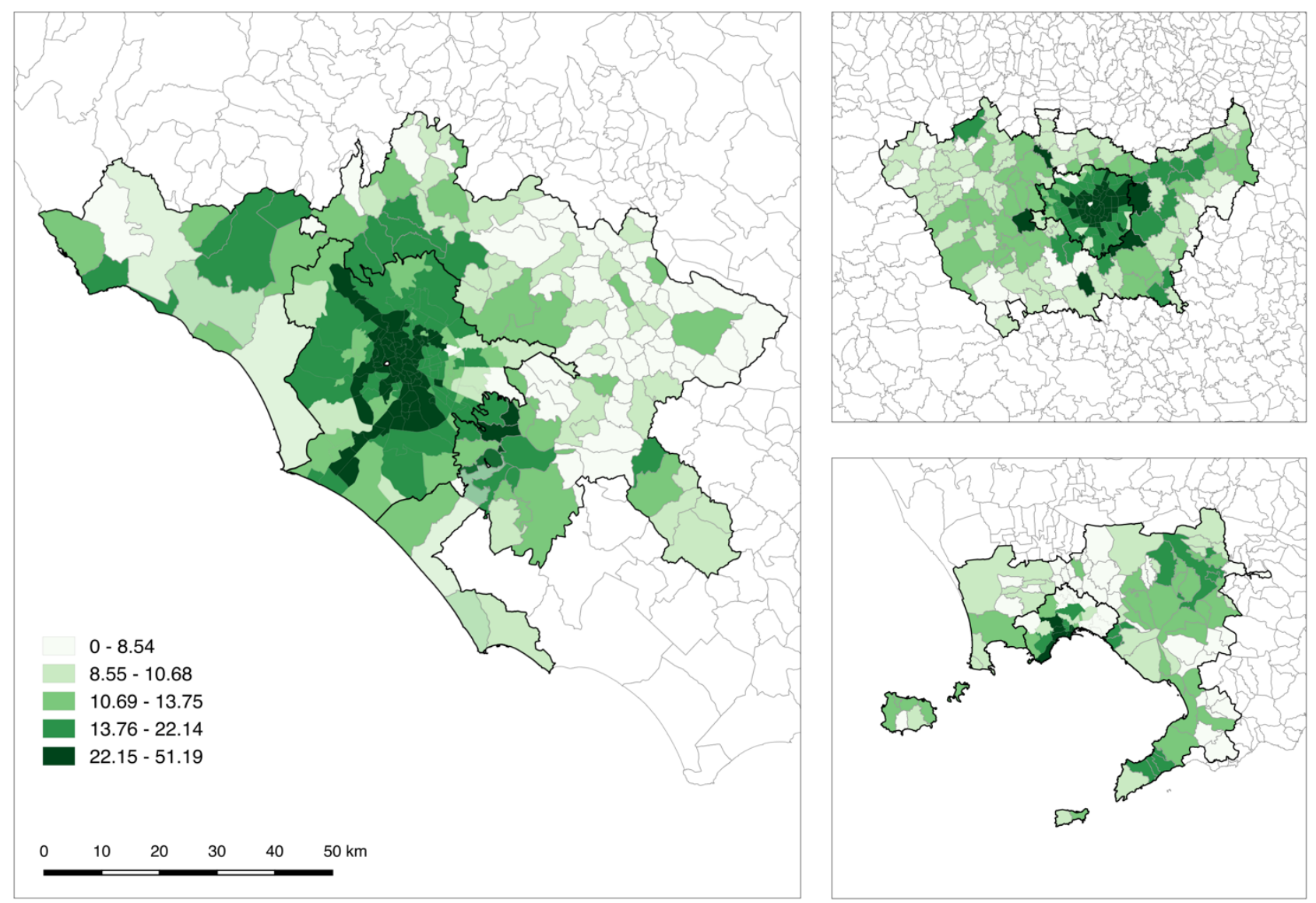

Source: Authors' analysis on ISTAT data.

Figure 11. Boxplots of graduates on the population with 20 years or more in 2011.

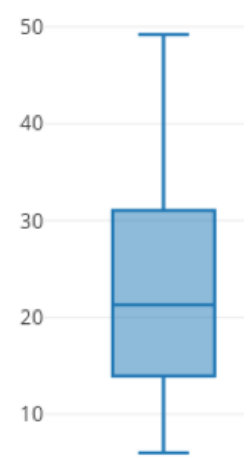

Roma Quartieri

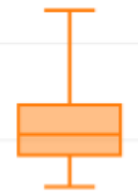

Roma Comuni

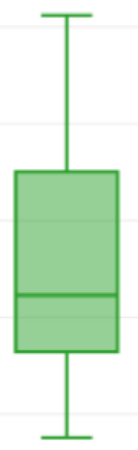

Milano Quartieri

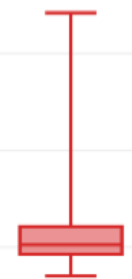

Milano Comuni
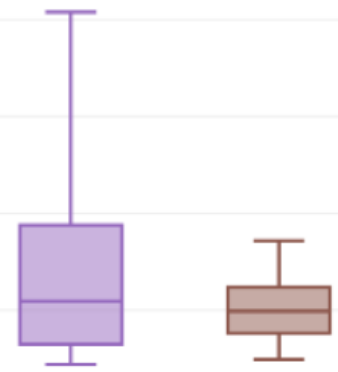

Napoli Quartieri 


\subsection{Employment rate}

Job opportunities are the outcome of educational ones. Large differences between centre and outskirts still remain about employment, although the situation is more complex and includes some particular cases. Being employed does not just mean having an income, it also and above all means being part of a community, self-realization and social inclusion: for these reasons the geography of employment and unemployment are symptomatic of territorial divides. Available data are taken from the 2011 Census, and therefore precede the serious recession of the subsequent years, which is why we show the employment rate, as it is less subject to economic cycles than the unemployment rate. These data are in any case the only chance we have to explore these phenomena at district level, and should therefore be considered more from the point of view of the differences between the urban areas than as absolute values, since it is well-known and enduring that Milan has a higher average than Rome, which in turn has a much higher average than Naples (Figures 12 and 13).

Figure 12. Maps of employment rate on the population aged 15 years or more in 2011.
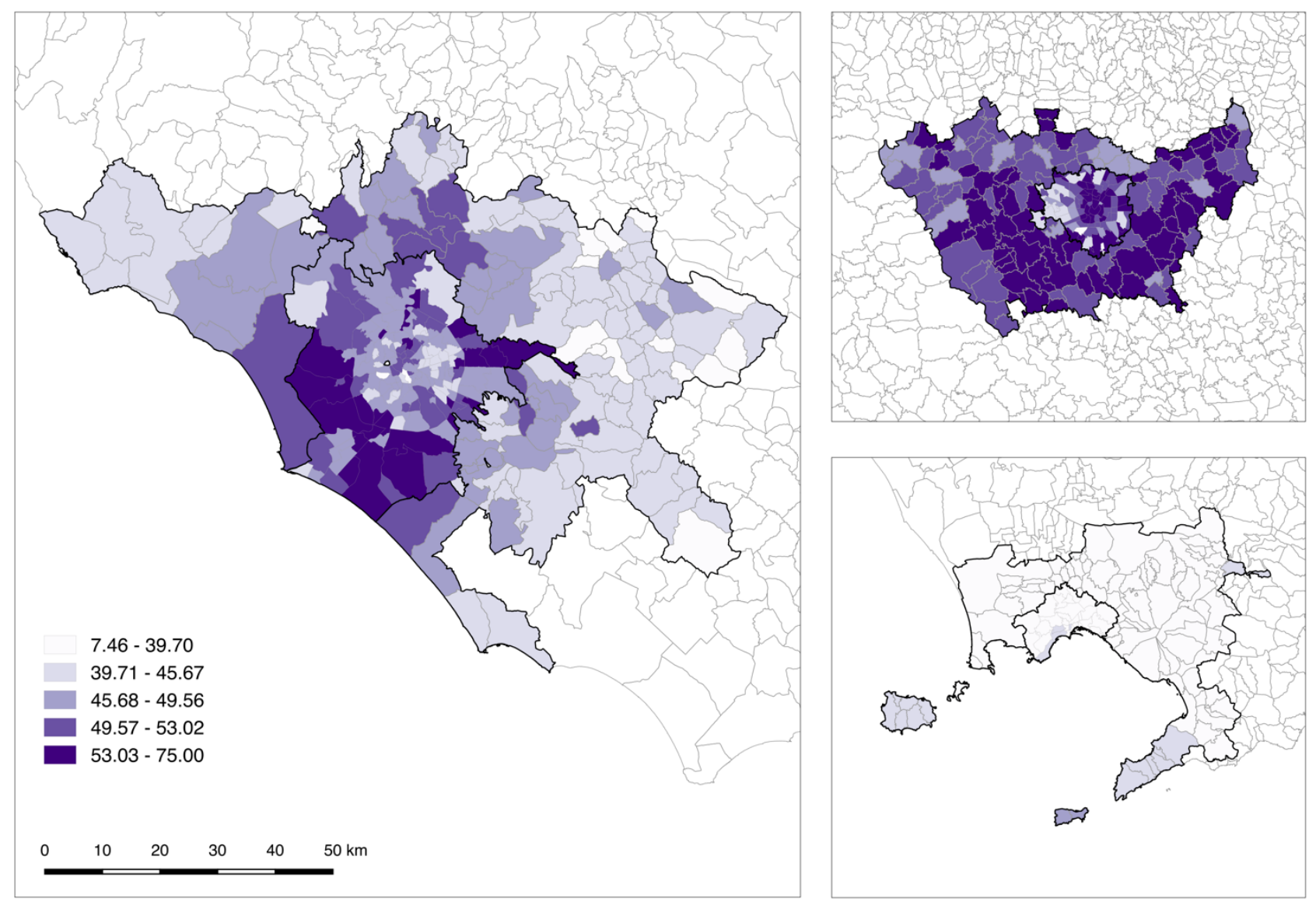

Source: Authors' analysis on ISTAT data. 
The International Journal
ENTREPRENEURSHIP AND SUSTAINABILITY ISSUES

ISSN 2345-0282 (online) http://jssidoi.org/jesi/

2018 Volume 6 Number 2 (December)

http://doi.org/10.9770/jesi.2018.6.2(31)

Figure 13. Boxplots of employment rate on the population aged 15 years or more in 2011.

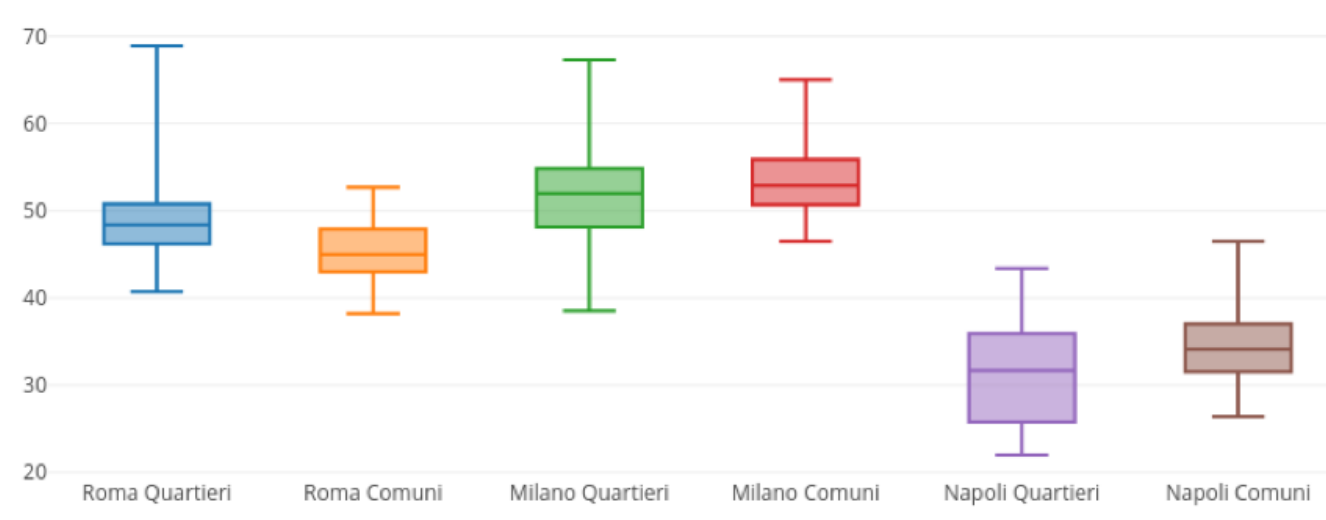

Source: Authors' analysis on ISTAT data.

The new residential areas on either side of the GRA house young families in which both adults usually work, either with stable or precarious jobs, and they are among the districts with the largest numbers of people in the workforce, more so than the traditionally well-off neighbourhoods to the north. The employment rate only exceeds 55\% in the outskirts to the south-west (Magliana, Malafede, Mezzocamino and Vallerano Castel di Leva) and to the east (Acqua Vergine, Sant'Alessandro, Lucrezia Romana, Barcaccia and Lunghezza), while it is just over $40 \%$ in the old working-class districts to the north (Tufello) and east (Torrespaccata, Casilino, Don Bosco and Gordiani), as well as in Ostia Nord on the coast. The employment rate is lower in the hinterland, only reaching 50-52\% in a few municipalities to the north (Fiano, Capena, Campagnano, Riano, Castelnuovo di Porto, Monterotondo and Formello) and south-east (Labico, Pomezia and Montecompatri), as well as in Fiumicino on the coast, while it is just over $40 \%$ (only considering the most populous municipalities) on the coast to the south of Rome (Nettuno and Anzio) and to the south-east (Velletri, Artena, Lariano, Cave and Colleferro).

The employment rate is higher on average in Milan than in Rome; it is only over $60 \%$ in three districts with low populations to the south-west (Muggiano) and south-east (Triulzo Superiore and Rogoredo), although it is between 55 and 60\% in the historical centre (Duomo) and in various neighbouring districts (Farini, Porta Romana, Garibaldi-Repubblica, Navigli, Sarpi, Centrale, Ticinese and Guastalla) or further out from the city centre to the north and east (Adriano, Bicocca, Loreto, Dergano and Lambrate), while it is below $45 \%$ in the outskirts to the south (Barona and Gratosoglio-Ticinello), west (Gallaratese, Lorenteggio and Forze Armate), east (Mecenate) and north (Quarto Oggiaro, Bovisasca and Niguarda - Cà Granda). There are also many medium-sized municipalities in the hinterland with an employment rate between 55 and 60\%, and therefore higher than the figures for Rome, to the east (Gessate, Settala, Mediglia, Pessano con Bornago, Vignate, Peschiera Borromeo and Pozzuolo Martesana), west (Vanzago, Settimo Milanese and Corbetta), south (Assago, Pieve Emanuele, Basiglio and Buccinasco) and north (Vimodrone), while it is below 50\% in the entire populous northern belt between Milan and Monza (Bresso, Cusano, Sesto San Giovanni, Cinisello Balsamo, Cologno, Arese, Novate, Garbagnate and Bollate) and in other municipalities to the west (Magenta and Corsico) and east (Melzo).

The absolute figures for Naples are lower than for Rome and the differences between districts are far more marked, since the employment rate is $43 \%$ in Posillipo, twice as much the very low rate of $22 \%$ in Scampia. This rate records figures of 40-43\%, typical of Rome's working-class areas, only in the well-off districts to the west (Posillipo, San Giuseppe, Chiaia, Vomero and Arenella), and actually falls below $30 \%$ in the populous outskirts to the north (Scampia, Miano, San Pietro a Patierno, Piscinola, Secondigliano and Poggioreale), east (San Giovanni 
a Teduccio, Ponticelli and Barra) and west (Soccavo), as well as in the Mercato and Pendino districts in the city centre. The employment rate is only over $40 \%$ in a few municipalities in the hinterland too, only on the islands (Capri, Anacapri, Casamicciola Terme, Serrara Fontana, Forio, Lacco Ameno and Ischia) and the Sorrentine peninsula (Sorrento, Massa Lubrense, Sant'Agnello, Piano di Sorrento, Meta and Vico Equense), as well as in Visciano to the north-east, while it is around 30\% in the populous municipalities to the north (Sant'Antimo, Caivano, Afragola, Crispano, Frattaminore, Grumo Nevano, Arzano, Qualiano, Casavatore, Casandrino, Frattamaggiore and Casoria), south-east (Ercolano, Torre Annunziata, Boscoreale, Torre del Greco and Boscotrecase) and west (Monte di Procida) of Naples.

\section{Conclusions}

The aim of this first comparative study was to have a better understanding of Rome's economic performance and social cohesion compared with the other large Italian metropolitan cities.

So - what is the extent of metropolitan inequality according to the evidence we collected? First of all, the province of Milan as a whole has an average income of over $€ 25,000$ with peaks of $€ 35,000$ in some hinterland municipalities. This is clearly different from Rome, where the average income is about $€ 20,000$ and is only over $€ 25,000$ in two municipalities in the north of the city: Formello and Grottaferrata. Average income falls below $€ 20,000$ in Naples, with the exception of Capri and Sorrento where it is $€ 21,000$. This difference in terms of income between the three cities is also confirmed by the employment figures: in some areas of Milan the employment rate is actually over $60 \%$, and just under $60 \%$ in many central districts, while it only falls below $50 \%$ in a few municipalities in the northern area. Naples comes nowhere near this figure, not even Posillipo with 43\%, let alone Scampia where only one person in five is employed. The employment rate in Rome is only over $55 \%$ in some new residential areas on the outskirts, on either side of the GRA, where young families have settled.

The data on graduates are particularly interesting as a way to underline the inequalities in terms of opportunities. The ratio between districts with the most graduates and those with the least is seven to one in Milan (51.2 vs 7.6), eight to one in Rome (49 vs 6) and nine to one in Napoli (40 vs 4.5). These data clearly illustrate the inequalities in Italy's three main metropolitan areas. Moreover, the further south you go in Italy the lower the absolute levels, since the territorial dualism in Italy is not only economic, to be measured by GDP, but also and above all in terms of opportunities; in today's complex society it is difficult to take advantage of them without academic qualifications. Furthermore, a district-based comparison of the data on education and employment shows how education has a clear impact on employment as well, since investing in education also helps to improve the quality and quantity of employed persons: this is nothing new and there is a great deal of literature on the subject, but it does no harm to refresh the memories of those who draw up public policies. This is not a field for local governments to deal with, although some policies such as lower taxes or a no-tax area for school canteens, or scholarships, as some regions have tried out could potentially be tools for combating early school leaving and low levels of tertiary education among the weakest sections of the population.

The territorial issues involved in employment, production and housing call for new and more complex interactions between the various approaches to urban problems. Italy's metropolitan areas will have to be a driving force in any strategic planning, on a par with the best examples provided by European cities - e.g. Barcelona, Lyon, Munich, Stockholm and Amsterdam -able to find resources, time, themes and ways to implement projects, together with a shared vision for their development. At the same time, our paper shows clear types of social exclusion and polarization between increasingly poor peripheral districts and well-off central ones, as if there were a kind of two-tier pace of growth. This phenomenon is more common in Naples and Rome, but it is also found in Milan, economic capital of the wealthy Northern Italy. These metropolitan areas are coming out 
of the worst crisis Italy has ever experienced, with a new class of poor people found not only in the outskirts and in the less well-off social groups but also among the middle class. Local and national governments cannot ignore this situation; the weakest sections of society have been unable to reap the benefits of the growth in the quaternary sector that has characterized Milan, Rome and Naples after the last decade, albeit to differing degrees. Scant attention has been paid to the peripheral areas, poverty has not been reduced and non-specialized workers are increasingly subject to forms of social exclusion. The middle class is trying to cope with the increase in the cost of living and in property prices, which are still often prohibitive, despite falling in recent years. Now would be a good time to revive social housing policies that have been on hold for decades. Too many people are excluded owing to a lack of opportunities, of social occasion, of inclusive social relationships and of institutions able to carry out their tasks. This shortfall needs to be addressed using all the tools available to encourage the creation of social capital.

Lastly, our paper reveals the need for specific policies, not only for the various metropolitan areas but also within them. In order to combat the emergence of inequalities in metropolitan areas, it is important to put people at the heart of policies, or rather their needs above anything else. To find the right way to achieve this, and to avoid stereotypes, data-driven policies are needed to enable national and local authorities to identify real needs and combat the various and new forms of marginality and social exclusion.

\section{References}

Amin, A., Thrift, N., 1994. Cities: reimagining the urban, Blackwell (Oxford, UK and Cambridge, Mass) http://www.polity.co.uk/book.asp?ref=9780745624136

Ascher, F., 1995. Métapolis ou l'avenir des villes, Odile Jacob, Paris. https://www.persee.fr/doc/flux 1154-2721 1996 num 12261754

Boschma, R.A., Iammarino, S., 2009. Related Variety, Trade Linkages and Regional Growth, Economic Geography, 85 (3): $289-311$. https://doi.org/10.1111/j.1944-8287.2009.01034.X

Camagni, R., 1998. Principi di economia urbana e territoriale, Carocci Roma, p. 9.

Cohendet, P., Grandadam, D., Simon, L., 2010. The Anatomy of the Creative City, Industry and innovation, 17(1): 91-111. https://doi.org/10.1080/13662710903573869

De Muro, P., Monni, S., Tridico, P., 2011. Knowledge-based economy and social exclusion: shadow and light in the Roman socioeconomic model, in "International Journal of Urban and Regional Research", 35 (6), pp. 1212-1238. https://doi.org/10.1111/j.1468$\underline{2427.2010 .00993 . x}$

De Muro, P., Monni, S., Tridico, P., 2012. "Rome. A tale of two cities”, in Martinelli F., Moulaert F., Novy A. (eds.), Urban and Regional Development Trajectories in Contemporary Capitalism, London, Routledge.

Duranton, G., Puga, D., 2005. From Sectoral to Functional Urban Specialization, Journal of Urban Economics, 57(2): 343-370. $\underline{\text { http://dx.doi.org/10.1016/i.jue.2004.12.002 }}$

Florida, R., 2002. The Rise of the Creative Class: And How it's transforming work, leisure, community and everyday life. New York: Perseus Book Group.

Glaeser, E.L., 1999. Learning in cities, Journal of Urban Economics, 46(2): $254-277$. https://kopernio.com/viewer?doi=10.1006/juec.1998.2121\&route=1 
Glaeser, E.L., 2010. Agglomeration Economics, The University of Chicago Press. https://www.press.uchicago.edu/ucp/books/book/chicago/A/bo8143498.html

Gaschet, F., Lacour, C., Puissant, S., 2011. La Metropolisation 15 ans apres, Cahiers du GREThA, 13. http://cahiersdugretha.ubordeaux4.fr/2011/2011-13.pdf

Kiselitsa, E.P., Shilova, N.N., Liman, I.A, Naumenko, E.E. 2018. Impact of spatial development on sustainable entrepreneurship, Entrepreneurship and Sustainability Issues, 6(2) 890-911. http://doi.org/10.9770/jesi.2018.6.2(28)

Landry, C., 2000. The Creative City: A Toolkit for Urban Innovators. London: Earthscan.

Lelo, K., Monni, S., Tomassi, F., 2017. "Roma, tra centro e periferie: come incidono le dinamiche urbanistiche sulle disuguaglianze socioeconomiche" [Rome centre and periphery: effects of urban dynamics on socio-economic inequalities], Roma Moderna e Contemporanea, 25 (1-2): 131-146.

Lelo, K., Monni, S., Tomassi, F., 2018. “Disuguaglianze metropolitane: un confronto con Milano e Napoli” in d'Albergo, E., De Leo, D. (2018), Politiche urbane per Roma: le sfide di una capitale debole. Sapienza Università Editrice, Roma: 17-35.

Lelo, K., 2017. Dynamics of the creative sector between Rome and the Sea, International Studies. Interdisciplinary Political and Cultural Journal 19(1): 45-60. file:///C:/Users/Manuela/Downloads/ipcj-2017-0004.pdf

Leroy, S., 2000. Sémantiques de la métropolisation, L'Espace Géographique, 1: 78-86. https://www.persee.fr/doc/spgeo 0046$\underline{24972000 \text { num } 29 \quad 1 \quad 1969}$

Mikhaylov, A. S., 2018. Socio-spatial dynamics, networks and modelling of regional milieu, Entrepreneurship and Sustainability Issues, 5(4): 1020-1030. https://doi.org/10.9770/jesi.2018.5.4(22)

Ovalle, M., Marquez, J., Salomon, S., 2004. A compilation on knowledge cities and knowledge-based development, Journal of Knowledge Management, 8(5): 107-127. https://doi.org/10.1108/13673270410558819

Pavia, R., 2002. Babele: la città della dispersione, Meltemi editore, Roma.

Sassen, S., 1996. The Global Cities: New York, London, Tokyo. Pinceton University Press.

Soja, E.W., 2000. Postmetropolis: critical studies of cities and regions, Blackwell (Oxford, UK and Cambridge, Mass) 
Keti LELO is Assistant professor in Economic history at Roma Tre University, Department of Business Studies. Her main research interests are in the fields of urban economics, urban history, spatial analysis and econometrics. She holds a degree in Architecture from Sapienza University of Rome (Italy), a Master of Science in Geoinformation for urban applications from the International Institute for Aerospace Survey and Earth Sciences (Enschede, The Netherlands), a Ph.D. in Geomatics from Sapienza University of Rome (Italy) and a Ph.D. in Economics from Roma Tre University (Italy).

ORCID ID: orcid.org/0000-0002-2009-3772

Salvatore MONNI is Associate Professor of Economic Policy and Director of the Master Program in "The Cooperative Firm: Economics, Law and Management", at Roma Tre University, Department of Economics. His current main research and publications are in the fields of development economics and policy. Salvatore is a graduate from Sapienza University of Rome (Italy), holds a Master of Arts in Development Economics from the University of Sussex (Brighton, UK) and a Ph.D. in Economics from Roma Tre University (Italy). He is principal investigator of CLUSDEV MED (Cluster Development Med), an H2020 MSCA RISE project.

ORCID ID: orcid.org/0000-0002-6326-5714

Federico TOMASSI is researcher at the Italian Agency for territorial cohesion, Rome. He holds a degree in economics, and a PhD in socio-economic and statistical studies (SESS EuroPhD) from Sapienza University of Rome. Research interests: public economics, social policies, electoral studies, urban and territorial analysis, regional and cohesion policies.

ORCID ID: orcid.org/0000-0002-3096-5255

Register for an ORCID ID:

https://orcid.org/register

Copyright (C) 2018 by author(s) and VsI Entrepreneurship and Sustainability Center

This work is licensed under the Creative Commons Attribution International License (CC BY).

http://creativecommons.org/licenses/by/4.0/

(c) (i) Open Access 